\title{
Epidemiology of spinal pain in a population of schoolchildren from Spain
}

\author{
Manuel Fraiz Barbeito, Graduate, Sara Rey Veiga, Graduate, Yoana González, Ph.D. ${ }^{b}$ \\ Iria Da Cuña Carrera, Ph.D. ${ }^{b}$, Alejandra Alonso-Calvete, Graduate ${ }^{c}$ and \\ María Teresa Santamaría Solís, M.D. ${ }^{a}$
}

\begin{abstract}
Introduction. Spinal pain is one of the main reasons for seeking care; it usually appears during school age, increases with age, and is related to certain risk factors. The objective of this study is to analyze the prevalence of spinal pain among schoolchildren and examine associated factors.

Population and methods. Cross-sectional study with a questionnaire administered to schoolchildren aged 9-11 years. The prevalence of pain, physical activity, spine self-care, backpack use, and electronic device use were analyzed.
\end{abstract}

Results. A total of 329 subjects were analyzed. The prevalence of spinal pain is $34.3 \%$, with no differences observed between sexes. Pain severity is considered mild, with a mean severity of $1.99 \pm 2.54$ over 10 according to the Wong-Baker FACES ${ }^{\circledast}$ scale; in more than $50 \%$ of cases, pain had a short duration (less than 12 hours). Cervical pain was referred by $22.2 \%$ of schoolchildren, whereas dorsal and lumbar pain were reported by $14 \%$ and $11.9 \%$, respectively. In addition, $47.9 \%$ referred pain in more than one region of the spine. Also, $73.3 \%$ of schoolchildren did physical activity outside school hours and 90.6\% used electronic devices. An association was observed between the presence of pain and adequate postural hygiene habits.

Conclusions. Schoolchildren referred spinal pain that was mild and short in duration, often in the cervical region. The association with risk factors indicates that children who referred pain have better postural habits.

Key words: back pain, epidemiology, child development, preventive health services, spine.

http: / / dx.doi.org/10.5546/ aap.2021.eng.364

To cite: Fraiz Barbeito M, Rey Veiga S, González González Y, Da Cuña Carrera I, et al. Epidemiology of spinal pain in a population of schoolchildren from Spain. Arch Argent Pediatr 2021;119(6):364-369.

\section{INTRODUCTION}

Between $60 \%$ and $80 \%$ of the world population suffers a spinal pain event throughout their lives. These events often start during childhood and adolescence, with a prevalence similar to that of adults, and is a common problem in the early stages of life. ${ }^{1-4}$

Risk factors that predispose to spinal pain in this stage have been described, including a sedentary lifestyle, competitive sports, inadequate postural habits, backpacks with excess weight, and school furniture that is not adapted to the school progress. ${ }^{5-7}$

In a meta-analysis, Calvo-Muñoz et al., ${ }^{8}$ indicated that there were no significant differences in the prevalence of spinal pain during childhood among continents or differences between sexes. However, it showed that spinal pain increased with age: from $18.2 \%$ at 10 years old to $65.6 \%$ at 16 years old. Other studies have reported differences between sexes and indicated that girls suffer lumbar pain more often, ${ }^{9}$ and even a higher prevalence of spinal pain based on age, and pointed out that during the growth acceleration period occurring between 7 and 11 years old, poor postural habits are acquired. ${ }^{10}$

Considering that spinal pain may start at an early age and remain present until adult age, it is critical to implement prevention strategies by identifying symptoms and risk factors in advance. Prior studies have described that school age is the critical time for intervention in these cases, with the implementation of preventive activities aimed at correcting poor posture, counteracting muscle imbalance, and improving postural hygiene..$^{11,12}$ 
However, it is necessary to know in depth the prevalence of spinal pain at each school given its multifactorial origin so as to implement prevention programs tailored to schoolchildren needs. Thus, the objective of this study was to analyze the prevalence of spinal pain in a population of schoolchildren and examine potential associated factors.

\section{POPULATION AND METHODS}

During 2019, a cross-sectional, multicenter study was carried out under the coordination of the Galician Health Service and implemented in 18 public schools from Pontevedra (Galicia, Spain), which participated voluntarily.

Inclusion criteria were: a) agreement to participate by the school and parents, and b) age between 9 and 11 years, based on prior studies. . $^{1,210}$

Exclusion criteria were: a) children who did not attend school on the date scheduled for the study, and b) children with an alteration that prevented conducting the process.

The sample size was estimated based on prior studies, ${ }^{13-16}$ using a percentage variable of spinal pain among schoolchildren $(34 \%$ in 1400 children); for this study, the sample size was 300 subjects, with a $4.7 \%$ precision and a $95 \%$ confidence level.

Data were collected using an ad hoc questionnaire that included 15 close-ended questions with multiple choice answers, based on prior studies, ${ }^{13-18}$ and adapted to the present study based on authors' consensus.

The questionnaire was answered by schoolchildren and supervised by teachers and the investigators of this study. The printed questionnaire was delivered to the schools; and investigators were responsible for collecting them afterwards and managing them for analysis. The questionnaire collected the following categories: a) demographic data, b) prevalence of pain in the past month (location in the cervical, dorsal or lumbar region, duration and severity based on the Wong-Baker FACES ${ }^{\circledR 19}$ visual analogue scale, that rates pain from 0 [no pain] to 10 [worst pain experienced], c) associated factors (physical activity, knowledge about spine self-care, postural hygiene, adequate or inadequate backpack use, and weekly use of electronic devices). The complete questionnaire is shown in the Annex.

Ethical considerations: This study was approved by the Ethics Committee of the Galician Health Service (2019/094) and conducted in accordance with all the principles of the Declaration of Helsinki. Since subjects were minors, all the information about the study was described to parents, who signed an informed consent for participation, and children were asked for their agreement.

Statistical analysis: The SPSS software, version 19 for Windows was used for data statistical analysis. Qualitative variables were compared using a $\chi^{2}$ test, whereas mean values were compared with Student's $t$ test and an analysis of variance (ANOVA). The significance level was established at 0.05 .

\section{RESULTS}

The questionnaires completed by 329 schoolchildren (50.5\% girls) were analyzed. The results are shown in Tables 1 and 2 and detailed below.

\section{Prevalence of spinal pain in the past month}

The prevalence of spinal pain was $34.3 \%$, and no significant differences were observed between sexes. In relation to pain duration, in 272 schoolchildren $(82.67 \%)$ it lasted less than 12 hours; in $30(9.11 \%)$, between 12 and 24 hours; in $18(5.47 \%)$, between 1 and 7 days; and in $9(2.73 \%)$, more than 1 week. In addition, pain was categorized as mild based on the Wong-Baker FACES $^{\circledR}$ (mean pain severity: $1.99 \pm 2.54$ over 10 ).

\section{Pain location}

Out of all schoolchildren with pain $(n=113)$, almost $50 \%$ suffered it in more than 1 region of the spine $(47.9 \%)$. Most commonly, pain was located in the cervical region (22.2\%), followed by the dorsal region (14\%) and, to a lower extent, the lumbar region (11.9\%), as described in Table 1.

\section{Physical activity}

Out of all schoolchildren, $73.3 \%$ did physical activity outside school hours. In relation to the number of days per week, $47.1 \%$ of participants did physical activity 2-3 days per week, whereas $22 \%$ did it 4 or more days per week, and $30.9 \%$, only 1 day per week. In relation to the type of activity, among those who did physical activity, $34.3 \%$ played team sports; $18.8 \%$, water sports; $7.6 \%$, fighting sports; $7 \%$, track and field; $6.4 \%$, gymnastics; $4 \%$, racket sports; $3.3 \%$, skating; and $2.7 \%$, cycling. The remaining $15.9 \%$ stated that they played sports outside school hours but did not tell which one. 


\section{Electronic device use}

Electronic devices were used by $90.6 \%$ of schoolchildren. In detail, $56.5 \%$ used them 1-2 days per week and $33 \%$, more than 3 days per week.

\section{Postural hygiene}

An association was observed between pain and adequate postural habits: schoolchildren whose pain was worse and lasted longer had better postural habits, both when getting out of bed correctly $(p=0.06)$ and when arranging the books in their backpack $(p=0.045)$. In addition, when lumbar pain was prevalent, subjects had better habits for getting out of bed ( $p=0.007)$ and avoided sleeping in the prone position, considered inadequate $(p=0.03)$.

\section{DISCUSSION}

The objective of this study was to analyze the prevalence of spinal pain in a population of schoolchildren aged 9-11 years and examine potential associated factors. The main outcomes showed that one-third of participants had suffered spinal pain in one or more regions in the past month, predominately in the cervical region, which had lasted few hours and was mild. In addition, schoolchildren with pain had significantly better postural hygiene habits than those who did not, possibly because they tried to avoid triggering the sensation of pain.

In this study, the prevalence of spinal pain was $34.3 \%$, close to that established in prior studies, which was between $12 \%$ and $33 \%{ }^{8}$ for the population of schoolchildren. In this study, the cervical region was most frequently affected, followed by the dorsal and lumbar regions. However, prior studies referred that the lumbar region was the most common location for pain at an early age, but, in many cases, they did not analyze the cervical region. ${ }^{8,9}$ This had been studied by Martínez-González et al., ${ }^{20}$ who concluded that children with lumbar pain had a future incidence of cervical pain between $12 \%$

TABLE 1. Descriptive statistics of pain, physical activity, and electronic device use $(n=329)$

\begin{tabular}{|c|c|c|c|}
\hline Variables & Answer & $\mathbf{n}$ & Percentage $(\%)$ \\
\hline Pain in the past month & $\begin{array}{l}\text { No } \\
\text { Yes }\end{array}$ & $\begin{array}{l}216 \\
113\end{array}$ & $\begin{array}{l}65.7 \\
34.3\end{array}$ \\
\hline Cervical pain & $\begin{array}{l}\text { No } \\
\text { Yes }\end{array}$ & $\begin{array}{c}255 \\
73\end{array}$ & $\begin{array}{l}77.5 \\
22.2\end{array}$ \\
\hline Dorsal pain & $\begin{array}{l}\text { No } \\
\text { Yes }\end{array}$ & $\begin{array}{c}282 \\
46\end{array}$ & $\begin{array}{c}85.7 \\
14\end{array}$ \\
\hline Lumbar pain & $\begin{array}{l}\text { No } \\
\text { Yes }\end{array}$ & $\begin{array}{c}289 \\
39\end{array}$ & $\begin{array}{l}87.8 \\
11.9\end{array}$ \\
\hline Pain duration & $\begin{array}{l}<12 \text { hours } \\
12-24 \text { hours } \\
1-7 \text { days } \\
\text { More than } 1 \text { week }\end{array}$ & $\begin{array}{l}176 \\
34 \\
18 \\
10\end{array}$ & $\begin{array}{c}53.5 \\
10.3 \\
5.5 \\
3\end{array}$ \\
\hline Pain severity & $\begin{array}{l}\text { No hurt } \\
\text { Hurts little bit } \\
\text { Hurts little more } \\
\text { Hurts even more } \\
\text { Hurts worst }\end{array}$ & $\begin{array}{c}163 \\
44 \\
67 \\
36 \\
4\end{array}$ & $\begin{array}{c}49.5 \\
13.4 \\
20.4 \\
10.9 \\
1.2\end{array}$ \\
\hline Sports outside school & $\begin{array}{l}\text { No } \\
\text { Yes }\end{array}$ & $\begin{array}{c}87 \\
241\end{array}$ & $\begin{array}{l}26.4 \\
73.3\end{array}$ \\
\hline Frequency of sports & $\begin{array}{l}\text { Never } \\
1 \text { day/week } \\
\text { 2-3 days/week } \\
4 \text { or more days/week }\end{array}$ & $\begin{array}{c}36 \\
54 \\
155 \\
74\end{array}$ & $\begin{array}{l}10.9 \\
16.4 \\
47.1 \\
22.5\end{array}$ \\
\hline Electronic device use & $\begin{array}{l}\text { No } \\
1-2 \text { times/week } \\
3-4 \text { times/week } \\
\text { Every day }\end{array}$ & $\begin{array}{c}31 \\
186 \\
57 \\
53\end{array}$ & $\begin{array}{c}9.4 \\
56.5 \\
17.3 \\
16.1\end{array}$ \\
\hline
\end{tabular}


and $50 \%$. In this regard, the presence of cervical pain as the most prevalent in a young population may result from an inadequate posture at school (18.5\% sat on the edge of the chair, $15.5 \%$ sat with their feet dangling, 30.1\% carried their backpack on one shoulder or with one hand, and $17.6 \%$ carried their backpack by the handle with one hand), and poor postural hygiene habits (7\% slept in the prone position, $10 \%$ sat with one leg tucked under, and 3.7\% sat on their knees). However, one factor stands out above the rest and that is the use of electronic devices during leisure time (90.6\% of schoolchildren), which has increased progressively and causes children to maintain a bad posture in the cervical region and upper limbs, many times for several hours at a time, in addition to reducing time spent on other, more active leisure activities ${ }^{17}$ and is related to important health problems, like video game addiction and obesity. ${ }^{21}$ In addition, prior studies reported how the use of backpacks may have an impact on cervical pain, mostly due to their design, but also to the way books are arranged and the overall weight carried, which many times exceeds the recommended limit. ${ }^{1,22-25}$ As observed in this study, schoolchildren have developed a series of potentially damaging habits for their spine, both at school and in their daily life. Most studies conducted to prevent spinal pain in this stage have mainly focused on analyzing school furniture and establishing the ideal dimensions to reduce the risk for pain or discomfort. ${ }^{26-29}$ However, it is worth noting that the cause of a high percentage of these events is the lack of adequate postural hygiene habits, which are more easily acquired during childhood and maintained during adulthood. 5,10 Therefore, it is critical to consider all these factors when developing prevention programs for the school stage, so it is necessary to know the habits of schoolchildren to make the right interventions. Prior studies ${ }^{13-18}$ have conducted programs for the prevention of spinal pain during school age considering some of these factors and achieved good results in terms of students' education; however, many of these studies did not consider the hours spent by schoolchildren using electronic devices, which has demonstrated to be a risk factor that has to be taken into consideration at this time. ${ }^{10,30}$ Therefore, prevalence studies, such as this one, are necessary to provide updated data that allow restructuring prevention strategies and adapting them to each

TABLE 2. Descriptive statistics of spine self-care and backpack use $(n=329)$

\begin{tabular}{|c|c|c|c|}
\hline Variables & Answer & $\mathbf{n}$ & Percentage $(\%)$ \\
\hline Adequate sleep position & $\begin{array}{l}\text { Face up } \\
\text { Face down } \\
\text { Sideways }\end{array}$ & $\begin{array}{c}53 \\
23 \\
251\end{array}$ & $\begin{array}{c}16.1 \\
7 \\
76.3\end{array}$ \\
\hline How do you get out of bed? & $\begin{array}{l}\text { Straight up } \\
\text { First I sit on the bed }\end{array}$ & $\begin{array}{c}72 \\
256\end{array}$ & $\begin{array}{l}21.9 \\
77.8\end{array}$ \\
\hline How do you sit? & $\begin{array}{l}\text { With the back against the chair } \\
\text { On the edge of the chair } \\
\text { With one leg tucked under }\end{array}$ & $\begin{array}{c}232 \\
61 \\
33\end{array}$ & $\begin{array}{c}70.5 \\
18.5 \\
10\end{array}$ \\
\hline While you are sitting, do you...? & $\begin{array}{l}\text { Have your feet on the ground } \\
\text { Have your feet dangling } \\
\text { Sit with one leg tucked under } \\
\text { Sit on your knees }\end{array}$ & $\begin{array}{c}241 \\
51 \\
24 \\
9\end{array}$ & $\begin{array}{l}73.3 \\
15.5 \\
7.3 \\
3.7\end{array}$ \\
\hline What kind of backpack do you use? & $\begin{array}{l}\text { Backpack } \\
\text { Backpack with wheels }\end{array}$ & $\begin{array}{l}172 \\
153\end{array}$ & $\begin{array}{l}52.3 \\
46.5\end{array}$ \\
\hline How do you carry your backpack up and down the stairs & $\begin{array}{l}\text { On your back } \\
\text { With the backpack handle over } \\
\text { your shoulder } \\
\text { By the handle with one hand }\end{array}$ & $\begin{array}{c}167 \\
99 \\
58\end{array}$ & $\begin{array}{l}50.8 \\
30.1 \\
17.6\end{array}$ \\
\hline Schedule review and backpack arrangement & $\begin{array}{l}\text { Never } \\
\text { Every night } \\
\text { Every morning }\end{array}$ & $\begin{array}{c}29 \\
253 \\
42\end{array}$ & $\begin{array}{c}8.8 \\
76.9 \\
12.8\end{array}$ \\
\hline How do you arrange your books in your backpack? & $\begin{array}{l}\text { The heavier ones away from the back } \\
\text { The heavier ones close to the back } \\
\text { It is the same }\end{array}$ & $\begin{array}{c}80 \\
159 \\
82\end{array}$ & $\begin{array}{l}24.3 \\
48.3 \\
24.9\end{array}$ \\
\hline
\end{tabular}


population group.

In addition, the analysis of postural habits among schoolchildren with pain showed that those with lumbar pain have better habits in relation to how they sleep, get out of bed, and carry their backpacks. Putting this in perspective based on the scientific bibliography published to date is complicated because the relationship between pain and a change towards healthier habits has not been yet studied in the schoolchildren population. However, it is possible that schoolchildren who had lumbar pain may have sought strategies to avoid triggering the pain in certain positions that entail a risk for pain in that region, such as during sleep or while getting out of bed. ${ }^{31}$

In relation to physical activity in this sample of schoolchildren, $73.3 \%$ usually do physical activity and almost $50 \%$ do it 2-3 days per week, which is consistent with prior studies ${ }^{10}$ and the recommendations of the World Health Organization $^{32}$ to prevent a sedentary lifestyle and physical inactivity. The study of physical fitness in schoolchildren is becoming increasingly more importan $t^{33}$ given that it has been demonstrated that moderate and high levels of fitness reduce the risk for metabolic disorders, increase bone mineral density, improve emotional, social, and cognitive well-being, and improve motor competence, correlated to a reduction in spinal pain. ${ }^{30,34}$ For this reason, physical activity is considered one of the most important markers of health in children and adolescents and should be taken into account in school assessments in terms of health knowledge and promotion..$^{33}$ In addition, $22 \%$ of schoolchildren did physical activity 4 or more days per week, which may be counterproductive during extremely high growth stages,,$^{35}$ although a relation between these variables has not yet been established.

This study poses certain limitations that should be taken into account. First of all, the questionnaire was developed specially for this study and has not been validated. In addition, this study considered the number of days of electronic device use but not the hours spent using them each day, which may be relevant when establishing whether this is a factor associated with spinal pain. It may be assumed that the more hours spent in the same position, the greater the pain, ${ }^{27,29,30}$ but this study has not been able to demonstrate that. In addition, the analysis of sports practice has also been considered based on the number of days, but the intensity, frequency or daily training hours have not been studied, which may have led to a different result interpretation and a more in-depth analysis of the impact of sports practice among schoolchildren on the prevalence of spinal pain. The purpose of this study is to provide an answer to the need for updated data on the prevalence of spinal pain among schoolchildren in order to develop more adequate prevention programs from an early age. However, it is worth noting that data corresponding to subjects in different age or population groups may vary.

\section{CONCLUSION}

One-third of schoolchildren had spinal pain that was mild and short in duration, with no differences between sexes.

This study found that schoolchildren with lumbar pain have more adequate postural hygiene habits than those without pain.

Pain was more prevalent in the cervical region than in the lumbar area, as suggested to date.

\section{REFERENCES}

1. Calvo-Muñoz I, Gómez-Conesa A. Asociación entre las mochilas escolares y el dolor de espalda. Revisión sistemática. Fisioterapia. 2012; 34(1):31-8.

2. Brattberg G. Do pain problems in young school children persist into early adulthood? A $13 \square$ year follow $\square$ up. Eur J Pain. 2004; 8(3):187-99.

3. Fabricant PD, Heath MR, Schachne JM, Doyle SM, et al. The epidemiology of back pain in American children and adolescents. Spine (Phila Pa 1976). 2020; 45(16):1135-42.

4. Achar S, Yamanaka J. Back pain in children and adolescents. Am Fam Physician. 2020; 102(1):19-28.

5. Jackson C, McLaughlin K, Teti B. Back pain in children: a holistic approach to diagnosis and management. J Pediatr Health Care. 2011; 25(5):284-93.

6. Fraile García PA. Dolor de espalda en alumnos de primaria y sus causas. Fisioterapia. 2009; 31(4):137-42.

7. Strikovic V, Krasnik R, Zvekic-Svorcan J, Demesi-Drljan C, et al. Potential risk factors for back pain in children. $J$ Back Musculoskelet Rehabil. 2019; 32(5):749-54.

8. Calvo-Muñoz I, Gómez-Conesa A, Sánchez-Meca J. Prevalence of low back pain in children and adolescents: a meta-analysis. BMC Pediatr. 2013; 13:14.

9. Jones GT, Macfarlane GJ. Epidemiology of low back pain in children and adolescents. Arch Dis Child. 2005; 90(3):3126.

10. Kratěnová J, ŽEjglicová K, Malý M, Filipová V. Prevalence and risk factors of poor posture in school children in the Czech Republic. J Sch Health. 2007; 77(3):131-7.

11. Calvo-MuñozI, Gómez-Conesa A, Sánchez-Meca J. Eficacia de los tratamientos de fisioterapia preventivos para el cuidado de la espalda en niños y adolescentes. Revisión sistemática. Fisioterapia. 2011; 33(6):262-72.

12. Cardon G, Balagué F. Low back pain prevention's effects in schoolchildren. What is the evidence? Eur Spine J. 2004; 13(8):663-79.

13. Cardon GM, Haerens LL, Verstraete S, De Bourdeaudhuij I. Perceptions of a school-based self-management program promoting an active lifestyle among elementary schoolchildren, teachers, and parents. J Teach Phys Educ. 
2009; 28(2):141-154.

14. Dolphens M, Cagnie B, Danneels L, De Clercq D, et al. Long-term effectiveness of a back education programme in elementary schoolchildren: an 8-year follow-up study. Eur Spine J. 2011; 20(12):2134-42.

15. Moreira R, Akagi F, Wun P, Moriguchi C, Sato T. Effects of a school based exercise program on children's resistance and flexibility. Work. 2012; 41(Suppl 1):922-8.

16. Park J, Kim J. Effects of spinal health educational programs for elementary school children. J Spec Pediatr Nurs. 2011; 16(2):121-9.

17. Galindo Morales G, Lalana Josa M, Sola Martínez MB, Sola Antón J. Aprendizaje de hábitos posturales y de ejercicio físico saludables en niños sanos con problemas leves de columna vertebral. Rev Pediatr Aten Primaria. 2010; 12(46):215-25.

18. Foltran FA, Moreira RF, Komatsu MO, Falconi MF, Sato TO. Effects of an educational back care program on Brazilian schoolchildren's knowledge regarding back pain prevention. Rev Bras Fisioter. 2012; 16(2):128-33.

19. Wong DL, Baker CM. Pain in children: comparison of assessment scales. Pediatr Nurs. 1988; 14(1):9-17.

20. Martinéz-González M, Gómez-Conesa A, Hidalgo Montesinos MD. Programas de higiene postural desarrollados con escolares. Fisioterapia. 2008;30(5):223-30.

21. Oflu A, Yalcin SS. Uso de videojuegos en alumnos de la escuela secundaria y factores asociados. Arch Argent Pediatr. 2019; 117(6):e584-91.

22. Korovessis P, Koureas G, Papazisis Z. Correlation between backpack weight and way of carrying, sagittal and frontal spinal curvatures, athletic activity, and dorsal and low back pain in schoolchildren and adolescents. J Spinal Disord Tech. 2004; 17(1):33-40.

23. van Gent C, Dols JJ, de Rover CM, Sing RAH, de Vet HC. The weight of schoolbags and the occurrence of neck, shoulder, and back pain in young adolescents. Spine (Phila Pa 1976). 2003; 28(9):916-21.

24. Oka GA, Ranade AS, Kulkarni AA. Back pain and school bag weight-a study on Indian children and review of literature. J Pediatr Orthop B. 2019; 28(4):397-404.
25. Yamato TP, Maher CG, Traeger AC, Wiliams CM, Kamper SJ. Do schoolbags cause back pain in children and adolescents? A systematic review. Br J Sports Med. 2018; 52(19):1241-5.

26. Knight G, Noyes J. Children's behaviour and the design of school furniture. Ergonomics. 1999; 42(5):747-60.

27. Gómez-Conesa A, Méndez Carrillo F. Ergonomía en las actividades de vida diaria en la infancia. Fisioterapia. 2000; 22(3):130-42.

28. Heyman E, Dekel H. Ergonomics for children: An educational program for elementary school. Work. 2008; 31(2):253-7.

29. Legg S, Jacobs K. Ergonomics for schools. Work. 2008; 31(4):489-93

30. Cardon GM, de Clercq DL, Geldhof EJ, Verstraete S, de Bourdeaudhuij IM. Back education in elementary schoolchildren: the effects of adding a physical activity promotion program to a back care program. Eur Spine J. 2007; 16(1):125-33.

31. Furtado R, Jones A, Furtado RN, Jennings F, Natour J. Validation of the Brazilian-Portuguese version of the gesture behavior test for patients with non-specific chronic low back pain. Clinics (sao Paulo). 2009; 64(2):83-90.

32. Organización Mundial de la Salud. Actividad física. [Accessed on: June 14 $\left.{ }^{\text {th }}, 2021\right]$. Available at: https: / / www. who.int / es / news-room / fact-sheets / detail / physicalactivity

33. Santandera MD, Garcíac GC, Secchid MJD, Zuñiga M, et al. Valores normativos de condición física en escolares argentinos de la provincia de Neuquén: estudio Plan de Evaluación de la Condición Física. Arch Argent Pediatr. 2019; 117(6):e568-75.

34. Sedrez JA, Da Rosa MIZ, Noll M, Medeiros FdaS, Candotti CT. Risk factors associated with structural postural changes in the spinal column of children and adolescents. Rev Paul Pediatr. 2015; 33(1):72-81.

35. Seclén-Palacín JA, Jacoby ER. Factores sociodemográficos y ambientales asociados con la actividad física deportiva en la población urbana del Perú. Rev Panam Salud Pública. 2003; 14(4):255-64 


\section{ANNEX}

\section{SCHOOL WORKSHOP FOR THE PREVENTION OF BACK PAIN FOR SCHOOLCHILDREN ATTENDING $4^{\mathrm{TH}}$ AND $5^{\mathrm{TH}}$ GRADE OF PRIMARY SCHOOL}

SCHOOL:

SEX: Male (...)
GRADE:

DATE

AGE:
Right-handed (...)

1. In the past month, have you had back pain?

Yes (...) No (...)

2. In what area of the back have you felt pain?
a) Neck.
b) Middle area (dorsal).
c) Low area (lumbar).

3. In general, how long does back pain last?
a) Less than 12 hours.
b) Between 12 and 24 hours.
c) Between 1 and 7 days.
d) More than 1 week.

4. Rate your pain from 0 to 10 , based on the following scale:

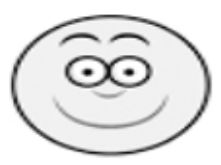

0

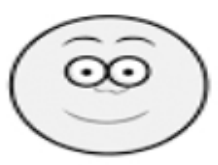

23

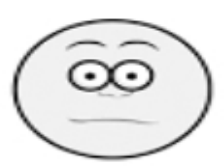

45

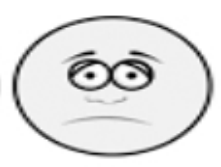

$6 \quad 7$

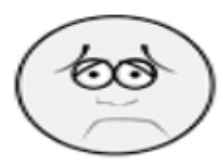

9

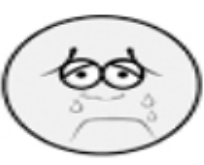

10

No hurt Hurts little bit Hurts little more Hurts even more Hurts worst

5. Do you play any sports regularly outside school?

Yes (...) No (...) Which sport?

6. How often do you play sports?
a) 1 day / week.
b) 2-3 days/week.
c) 4 or more days/week.
d) Never.

7. Do you play with game consoles, videogames, mobile phones, computer?
a) I do not play.
b) 1-2 times per week.
c) 3-4 times per week.
d) Every day.

8. The adequate sleep position is:
a) Face up.
b) Face down.
c) Sideways. 
9. How do you get out of bed?
a) Stand up facing up to get out of bed.

b) Sit on the bed first and then get up.

10. How do you sit?
a) With the back against the chair.
b) On the edge of the chair.
c) With one leg tucked under.

11. While you are sitting, do you...?
a) Have your feet on the ground.
b) Have your feet dangling.
c) Sit with one leg tucked under.
d) Sit on your knees.

12. What kind of backpack do you use?
a) Backpack.
b) Backpack with wheels.

13. When you climb up or down the stairs, do you?
a) Carry your backpack on your back.
b) Pass the backpack handle over your shoulder.
c) Carry the backpack by the handle with one hand.

14. When do you review your schedule and organize your backpack?
a) Every night.
b) Every morning.
c) Never.

15. How should books and notebooks be arranged in the backpack?
a) The heavier ones should be away from the back.
b) The heavier ones should be close to the back.
c) It is the same. 